\title{
A Inconfidência Mineira e Tiradentes vistos pela Imprensa: a vitalização dos mitos (1930-1960)*
}

Thais Nívia de Lima e Fonseca Universidade Federal de Minas Gerais

\section{RESUMO}

Este artigo analisa as apropriações, pela imprensa, das representações da Inconfidência Mineira e especialmente de Tiradentes, entre as décadas de 30 e 60 do século $\mathrm{XX}$, quando foi muito intensa a preocupação com a memória do movimento e de seu mais ilustre personagem. A análise da produção jornalística sobre o herói nacional procura identificar os principais elementos constituidores desses textos indicando, por um lado, a vitalidade dos mitos e, por outro, o poder persuasivo das associações estabelecidas entre o sacrifício heróico de Tiradentes e as condutas dos que se colocam como seus herdeiros, buscando no passado a legitimação para as ações do presente. Palavras-chave: Inconfidência Mineira; imprensa; representações políticas.

\section{ABSTRACT}

This article shows how Brazilian press appropriates the representations of the Inconfidência Mineira and specially of Tiradentes between the decades of 1930 and 1960. It intends to identify the main elements of these elaborations, such as the vitality of the national hero myth and the persuasive power of the associations between Tiradentes's sacrifice and his modern heirs. The legitimation of present actions is based on past events.

Keywords: Inconfidência Mineira; press; political representations.

No estudo das representações políticas a imprensa constitui fonte das mais expressivas. Seu papel como uma força política é amplamente reconhecido, e no Brasil, desde o século XIX, ela tem participado ativamente da vida política do País, sendo capaz de exercer influência, expressar posicionamentos, ajudando a construir ou a consolidar opiniões, como ocorreu, por exemplo, em relação à campanha abolicionista ${ }^{1}$. Há muito tempo os jornais têm dado espaço ao tema da Inconfidência Mineira, quase sempre para a exaltação de Tiradentes como herói e mártir, usando-o como modelo em discursos em geral de natureza nacionalista e/ou moralista. A história de Tiradentes passou a ocupar espaço na imprensa com o crescimento do movimento re- 
publicano na segunda metade do século XIX e, mais ainda, com a instalação da própria República. Desde então, artigos, poemas, reportagens, ensaios e outras modalidades de textos têm sido publicados prodigamente, sobretudo no momento da celebração da morte do herói, a 21 de abril.

Antes mesmo de tornar-se foco de interesse da historiografia, a Inconfidência Mineira já era tema de uma vasta produção de textos de natureza diversa. Levantamentos já bastante conhecidos indicam expressivo volume de publicações sobre ela ainda no século XIX². Artigos, conferências, discursos, romances, contos, peças de teatro, óperas e poemas já tomavam a Inconfidência Mineira e seus personagens como tema, na segunda metade do oitocentos, demonstrando a existência de um interesse que não pode ser reputado unicamente a uma construção oficial da memória da conspiração. É verdade que, naquele momento, uma parte do ainda incipiente movimento republicano tinha interesse na valorização da Inconfidência como fundadora da República e, por isso, estimulava sua difusão por diversos mecanismos. Mas creio ser possível perceber também outras formulações, provenientes de tradições culturais de significação mais ampla para uma parte da população, ao menos na região mais proximamente ligada aos episódios do movimento setecentista mineiro. Também é possível considerar as influências de uma cultura política mais enraizada, de caráter autoritário e personalista, derivada de práticas perceptíveis na longa duração, desde os tempos dos mandos dos potentados locais das áreas de mineração e dos sertões da Capitania das Minas Gerais.

Se a Inconfidência Mineira tem sido elemento de suporte a uma determinada construção historiográfica e a projetos e posicionamentos políticos desde as últimas décadas do século XIX, Tiradentes desponta como seu símbolo, síntese das idéias das quais o movimento seria o precursor, no Brasil. Ele se tornou, talvez, o personagem mais popular da história nacional, adquirindo contornos heróicos e status de mito político. Apesar de muito marcada pela ação dos republicanos e de seus interesses, a construção desse perfil de Tiradentes não se deveu apenas a eles. Da popularidade presumida à transformação em herói e mito político, Tiradentes percorreu um caminho sulcado pela ambiência cultural de seu próprio tempo e pela herança deixada por ela em tempos posteriores. Muitas de suas representações foram, sem dúvida, construídas e manipuladas, mas em torno de um imaginário social específico, que permitiu seu reconhecimento até certo ponto espontâneo. A ação política, por sua vez, promoveu sua consolidação pela utilização induzida, organizada e intensiva.

A criação e o enraizamento de mitos políticos, como é o caso de Tiradentes, devem ser entendidos na concretude das experiências e das referências sociais que "naturalizaram" a sua aceitação, permitindo sua circulação, seu reconhecimento e facilitando sua apropriação. Os elementos que com- 
põem as representações predominantes da Inconfidência e, sobretudo, de seu mártir - como as idéias de liberdade, coragem, abnegação, sacrifício, patriotismo - são parte integrante das experiências sociais, culturais e políticas da sociedade brasileira, desde o século XVIII. Sem essas experiências coletivas, as tentativas dos republicanos de entronizar Tiradentes como o herói máximo da nação, com as características que o eternizaram, não teriam obtido sucesso, pois não encontrariam ressonância junto à população, ou seja, não estariam imbuídas de referências reconhecíveis por ela. Não se pode esquecer, ainda, que os próprios republicanos também eram parte integrante daquela sociedade, compartilhando das mesmas experiências e, portanto, valorizando-as como referências na construção de sua visão da Inconfidência Mineira.

As primeiras obras sobre a Inconfidência Mineira, datadas da segunda metade do século XIX, produziram-se num contexto de disputas entre republicanos e monarquistas quando, sobretudo os primeiros, buscavam afirmação no cenário político brasileiro. É bastante conhecida a obra de Joaquim Norberto de Souza Silva que, em resposta ao movimento de entronização de Tiradentes levado a efeito pelos clubes republicanos, publicou, em 1873, a sua História da Conjuração Mineira ${ }^{3}$. As polêmicas suscitadas por sua abordagem - acusada de depreciar a imagem de Tiradentes - produziram outros trabalhos que procuraram demonstrar a "verdadeira" história do movimento e a "verdadeira" face de seu personagem mais conhecido. Um dos mais importantes foi Inconfidência Mineira - papel de Tiradentes na Inconfidência Mineira, de Lúcio José dos Santos ${ }^{4}$, publicado originalmente em 1927. No rastro desse movimento de reabilitação, ou antes, de defesa da integridade do herói republicano, outras obras vieram somar-se a uma bibliografia que se tornou vasta, porém pouco inovadora, marcada por abordagens de cunho marcadamente tradicional ${ }^{5}$.

Estes textos, escritos em épocas diversas, têm em comum a preocupação com a construção de uma versão para a Inconfidência Mineira na qual se acentua o caráter exaltador, nacionalista e patriótico. Buscando subsídios nos $\mathrm{Au}$ tos de Devassa, esses autores empenham-se na busca da "verdade" histórica, dissipadora de dúvidas sobre o real significado do movimento setecentista, sobre o papel desempenhado por seus protagonistas e, sobretudo, que reforce a legitimidade da Inconfidência Mineira como movimento precursor da Independência e de Tiradentes, como seu protomártir e herói máximo da nação. Em praticamente todos eles está presente a crítica, muitas vezes apaixonada, da obra de Joaquim Norberto e o cuidado na refutação, ponto por ponto, de sua versão dos fatos. Além disso, em muitos desses trabalhos nota-se uma indisfarçável conotação regionalista que procura, por meio da exaltação da Inconfidência, afirmar uma identidade regional, talvez a chamada "mineiridade”. Esta forma de abordagem está fortemente marcada por uma concep- 
ção de história de herança tradicional, bem aos moldes do Instituto Histórico e Geográfico Brasileiro, sobretudo em sua vertente republicana. São geralmente textos descritivos, fundamentados numa leitura linear nos Autos de Devassa da Inconfidência Mineira, excessivamente preocupados com uma correta cronologia, com a montagem de um perfil pessoal favorável de todos os inconfidentes - exceto, é claro, dos delatores — , maniqueístas e com discutível estruturação teórico-metodológica. Não obstante, são as matrizes a partir das quais a história da Inconfidência Mineira tem sido predominantemente construída e difundida, especialmente pelos meios de comunicação e pela escola. Curioso é que, mesmo quando provenientes de posicionamentos políticos distintos e, às vezes, opostos, o pano de fundo elaborado nestas obras, com a preocupação de enaltecer o movimento e seu herói, permanece inalterado.

A partir da década de 1960, alguns trabalhos mais consistentes dedicaram-se à discussão da Inconfidência em outras dimensões, mais preocupados com suas relações com a crise do Antigo Sistema Colonial, levantando a questão do caráter revolucionário do movimento e de seus limites, analisando as relações sociais presentes na conspiração, procedendo, enfim, a uma reflexão menos linear, menos "apaixonada" da Inconfidência e evitando, ao máximo, concentrar sua atenção na figura de Tiradentes ${ }^{6}$. Essa vertente demonstrava, evidentemente, uma reação contra a historiografia tradicional sobre o tema. Um desses trabalhos, Idéia de Revolução no Brasil, de Carlos Guilherme Mo$\mathrm{ta}^{7}$, inovou ao propor uma reflexão dos movimentos anti-coloniais do ponto de vista de suas formulações ideológicas e políticas, sem preocupar-se com a cronologia tradicional dos fatos ou a participação mais marcada dos personagens. Kenneth Maxwell, em seu A devassa da devassa ${ }^{8}$ verticalizou a análise aprofundando-se na documentação mais conhecida sobre a Inconfidência, articulando-a a outras fontes, propondo uma abordagem inovadora e mais complexa do movimento. Não obstante, cuidou de não negligenciar os indivíduos que dele participaram, na medida em que fixou, na análise da teia de relações sociais estabelecidas entre os grupos atuantes na Inconfidência, um dos alicerces de sua análise. Essa obra tornou-se uma referência fundamental nos estudos sobre a Inconfidência. Mais recentemente, João Pinto Furtado realizou um mergulho na análise relacional das fontes, promovendo uma releitura dos Autos de Devassa'. É mister ressaltar que alguns estudos não propriamente voltados para a Inconfidência Mineira, mas para o conjunto das sedições coloniais em Minas Gerais, muito têm contribuído para o avanço das reflexões sobre a natureza desses movimentos e sua inserção no universo colonial. Entre esses trabalhos merecem destaque os estudos de Laura de Mello e Souza e Carla Maria Junho Anastasia ${ }^{10}$.

A partir dos anos 90, uma reflexão mais crítica sobre o movimento, seu significado e sua historiografia, tem gerado alguns trabalhos inovadores. De- 
bates em eventos acadêmicos, organizados na ocasião das comemorações dos bicentenários da Inconfidência e do enforcamento de Tiradentes (em 1989 e 1992, respectivamente), trouxeram nova luz à discussão. Além de balanços da produção historiográfica sobre o tema, esses encontros provocaram a reflexão sobre a comemoração, suas representações, seus significados simbólicos, sua inserção no imaginário coletivo. Nesse momento foi possível perceber as possibilidades de outras vertentes, de novas abordagens para um objeto tão curtido e repisado, ao mesmo tempo que espinhoso e tratado quase sempre de forma uníssona. Os aportes da História Cultural, os estudos sobre o imaginário, o simbólico e as representações apareceram no cenário sinalizando os caminhos possíveis para a análise da Inconfidência Mineira sem os vícios nacionalistas da historiografia tradicional, e sem as generalizações das análises estruturais. Uma releitura das idéias, das leituras dos intelectuais setecentistas, a reflexão sobre o caráter construído do evento histórico, sobre suas apropriações a posteriori, a discussão sobre o mito e seu papel no cenário político e cultural brasileiro, foram algumas das possibilidades indicadas pelas discussões promovidas a partir do momento comemorativo ${ }^{11}$. Uma discussão importante, é verdade, apesar de concentrada, ainda, na reflexão teórica. Carecemos, portanto, do mergulho nas fontes. Nas tradicionais, como os Autos da Devassa, e nas menos exploradas, prenhes, no entanto, de potencial elucidativo, principalmente no âmbito da história da cultura, do imaginário e do simbólico. Estas esperam até agora pelo historiador da Inconfidência Mineira. Tiradentes ainda espera ser revelado, sem preconceitos, como o mito vivo que, de fato, é.

Alguns poucos trabalhos têm buscado esse manancial e têm aberto as fronteiras para os avanços neste campo. José Murilo de Carvalho já havia indicado alguns caminhos para a pesquisa dessa problemática, discutindo, em A formação das almas ${ }^{12}$, a construção do mito de Tiradentes pelos republicanos no final do século XIX. Seguindo a trilha traçada por Maurice Agulhon para a França ${ }^{13}$, Carvalho tratou da apropriação, no Brasil, de um conjunto de símbolos e mitos republicanos de matriz francesa, no processo de estruturação da República brasileira. Inspirados por esse trabalho, temos, já na década de 90, as análises de Eliana Dutra e de Sérgio Vaz Alkmin ${ }^{14}$, que se preocuparam, especialmente, com o processo de formulação de uma imagem sacralizada e cristianizada da Inconfidência Mineira e de Tiradentes, tomando como base os relatos dos frades que assistiram os inconfidentes em seu período de prisão no Rio de Janeiro ${ }^{15}$. Esse tipo de abordagem representa, de fato, um retorno aos documentos, a valorização de uma pesquisa empírica mais apurada, a busca de uma nova leitura, de aspectos ainda não tratados nestas fontes que, apesar de já muito utilizadas, ainda têm muito a revelar.

Apropriando-se das representações predominantes, sobretudo de Tira- 
dentes, fundadas num perfil sacralizado do alferes mineiro e sedimentado por aquela historiografia tradicional e nacionalista, os jornais produziram, principalmente ao longo do século XX, rico manancial de registros que permitem a análise de alguns dos períodos mais significativos da recente história política do Brasil. Utilizando-se dos mais diversos recursos - expressos em textos de natureza bastante variada - os jornais tiveram um relevante papel no processo de difusão e de consolidação dessas representações. Foram, além disso, poderosos instrumentos de legitimação de projetos políticos e de ideologias, e entre 1930 e 1960 expressaram de forma intensa as tensões vividas entre os grupos em conflito naquele momento.

Em Minas Gerais, uma grande intensidade dessas referências pode ser creditada à importância que o tema assumiu na construção e na manutenção de uma identidade regional, apropriada com bastante regularidade na prática política, desde as primeiras décadas do século XX. Não entrarei aqui na seara, certamente polêmica, da chamada "mineiridade", como elemento daquela identidade. É certo que esse traço identitário — trabalhado pelo imaginário não apenas em Minas Gerais, mas também em outras partes do Brasil — tem sido fartamente explorado, tanto pela literatura e pelos meios de comunicação quanto pela política. Não raro tem servido de suporte aos discursos sobre Tiradentes e sobre sua posição precursora no processo de independência do Brasil, como evidência de um suposto pioneirismo libertador dos mineiros e, em determinadas épocas, de sua proeminência no cenário político do País. Mas as apropriações das representações de Tiradentes não só ultrapassam, como não se sustentam em uma suposta mineiridade, e é por isso que esta última não constitui, aqui, objeto de reflexão, mesmo que apareça em muitos discursos sobre o tema. Interessa, no momento, acentuar como se produziram os olhares da imprensa sobre a Inconfidência Mineira e sobre a atuação de Tiradentes, especialmente em alguns momentos em que eles foram mais intensamente utilizados como instrumentos de valorização de posições políticas e de projetos de construção nacional.

Os textos sobre a Inconfidência Mineira e sobre Tiradentes, publicados nos jornais entre as décadas de 30 e 60 , possuíam autoria variada ${ }^{16}$ : historiadores de tendência tradicional, geralmente ligados aos institutos históricos; juristas; diplomatas; políticos; professores; cronistas, romancistas e poetas; jornalistas; não raro intelectuais católicos militantes. Às vezes também clérigos. Isso sem considerar os textos escritos para ou por crianças, em geral publicados nos cadernos destinados ao público infantil. Se havia uma grande variedade de autores, o mesmo não se pode dizer das temáticas. Claro, o tema de fundo é sempre Tiradentes ou a conspiração de uma forma geral. Mas no relevo, uma fastidiosa repetição: sínteses da história da Inconfidência Mineira, geralmente baseadas em obras mais conhecidas na época ${ }^{17}$; biografias 
de Tiradentes ou comentários sobre seu perfil e caráter; narrativas sobre a execução de Tiradentes, quase sempre com ênfase na crueldade e insensibilidade das autoridades portuguesas; em menor número, mas não menos enfáticas, as análises sobre a política colonial portuguesa e os abusos cometidos em nome dela.

Quando falo da fastidiosa repetição não me refiro apenas à pouca variação, mas à ocorrência de um quase-padrão de abordagem, o que às vezes faz da leitura dessas fontes um exercício de paciência. Por outro lado, é justamente essa repetição que permite perceber o movimento de circulação e de valorização das representações de Tiradentes e dos significados a elas atribuídos, bem como perceber as sutis modificações apresentadas em determinados momentos. Em meio às narrativas bastante previsíveis, destacavam-se as ligações estabelecidas entre os episódios do passado e os problemas e situações vividos no presente. Embora mantivesse seu perfil, Tiradentes podia ser utilizado diferentemente, conforme os interesses e as circunstâncias.

Muito raramente, encontram-se vozes dissonantes no concerto laudatório ao protomártir da Independência do Brasil. Mesmo textos satíricos preservavam o herói, enquanto teciam críticas ao governo, a políticos ou a outras figuras de relevo. Poucos se aventuraram a contestar, timidamente que fosse, o conjunto de imagens consagradas, como fez o escritor Eduardo Frieiro, logo refutado por outros ensaístas. Em artigo publicado no jornal Estado de Minas, ele se mostrava incomodado com o tom laudatório predominante:

Na Historiografia do Tiradentes, o tom apologético e a inflação verbal, exaltadamente patrióticos, próprios para despertar emoções para adolescentes, tornaram quase temerário o ponto de vista dos que consideram o drama da Inconfidência Mineira com certa frieza realista. Não tem faltado, entretanto, vozes autorizadas que subestimam a importância histórica da conjura larvar de 1789 e reduzam a proporções modestas o papel do homem afoito que pagou com a vida por falar demais e deitou a perder poetas, padres, doutores e militares pelo único crime de terem externado o seu inconformismo político ${ }^{18}$.

Frieiro trabalhou, neste artigo, com as idéias de Joaquim Norberto de Souza Silva e de Capistrano de Abreu, no intuito de demonstrar a existência de outras versões sobre a conspiração e sobre o papel de Tiradentes. Sua intenção ficou explicitada em suas perguntas: Houve na realidade, uma tentativa séria de levante? Foi o Tiradentes verdadeiramente o chefe dessa tentativa? ${ }^{19}$ Sua preocupação com a "verdade" sobre essa história levou-o a argumentos contrários à exaltação, mas isso não indica que fosse, ele próprio, partidário desses argumentos. Na verdade, ao final do artigo, Frieiro voltou à representação mais aceita que, mesmo considerando a possibilidade de um compor- 
tamento atrapalhado de Tiradentes, não alterou sensivelmente sua posição como mártir ou como herói, mesmo quando deixou entrever suas fraquezas:

O Tiradentes pagou por falar demais. Pagou mais que os outros porque era um mestiço, de casta inferior, o mais humilde dos indiciados na devassa. Sua mente inflamada, típica do indivíduo impulsivo e generoso que está sempre pronto a fazer justiça por seu próprio arbítrio, comprometeu irremediavelmente os personagens do tenebroso drama urdido pela polícia política do tempo, truculenta e feroz como todas as justiças políticas. Mas a dignidade que conservou na provocação, em contraste com a pusilanimidade de quase todos os indiciados, o holocausto de sua vida, exigido pelo absolutismo liberticida, o redimiram de todas as imprudências e leviandades. Sua sombra legendária de vítima do despotismo merece o respeito da História ${ }^{20}$.

Não obstante o afloramento de uma visão muito próxima ao objeto de sua própria crítica, o artigo de Frieiro não deixou de provocar objeções, publicadas em outro jornal de Belo Horizonte, algumas semanas depois. O autor, conhecido por seus textos e poemas laudatórios, refutava Frieiro:

Quem lê o volumoso processo da alçada, pode duvidar de todas as provas ali condensadas, menos das que apontam em Tiradentes o chefe virtual, o condutor popular da conjura “abominável”. Tiradentes resistirá sempre à negação dos Capistranos e dos Norbertos, às chamadas restrições eruditas de um ensaísta da força do nosso Eduardo Frieiro. Se o alferes era um baixo e desavisado demagogo, um dementado, como querem os seus restricionistas, por que lhe atribuem os magistrados que o julgaram "função principal" no movimento ? $^{21}$

Nessas posições ficam claros alguns aspectos importantes na construção do perfil heróico de Tiradentes, que acaba por utilizar suas fraquezas, sua situação social inferior, e até mesmo seus supostos erros, como elementos de valorização de sua pessoa e de sua atuação. No fim, todos acabam por concordar que, pela morte, ele superou todas as restrições, qualquer que fosse sua natureza, e fez despontar, postumamente, todas as suas "verdadeiras" qualidades. Não é difícil perceber as possibilidades de aceitação dessa representação — e, também, de sua manipulação - junto ao público em geral, a partir de uma percepção deste Tiradentes que, apesar de pobre e fraco, poderia simbolizar as conquistas de toda uma nação.

Os textos aparecidos na imprensa entre as décadas de 30 e 60 do novecentos, embora perpassados pelo discurso laudatório mais tradicional, podem ser reunidos, basicamente, em três estilos de tratamento do tema, aos quais denominei o historiográfico, o romanesco, e o cristão. Além deles, há ain- 
da a transcrição de discursos proferidos durante as comemorações de 21 de abril, importantes registros acerca das apropriações políticas das representações aqui examinadas. Evidentemente, propor uma "tipologia" é correr o risco de uma certa redução. No entanto, creio poder fazê-lo com o intuito de mostrar tendências que tiveram grande vitalidade, não sendo exclusivas do período em foco neste momento. Ademais, esses textos eram, não raro, o pano de fundo para a expressão de posicionamentos políticos e para o confronto entre eles.

O primeiro estilo, mais comum, consistia na reelaboração contínua de sínteses da história da Inconfidência Mineira e de Tiradentes, inspiradas nas obras, na época, mais conhecidas sobre o tema (as de Joaquim Norberto e de Lúcio dos Santos e, mais ao final da década de 50, de Augusto de Lima Júnior). Os jornais não se cansavam de transcrever trechos dos Autos de Devassa, principalmente da sentença da alçada que, certamente, tornou-se muito conhecida por sua intensa reprodução nas páginas desses periódicos. Ao fazê-lo estavam, evidentemente, acentuando o episódio da morte do herói e, não raro, reforçando uma visão negativa da colonização portuguesa no Brasil, que seria culpada, em última instância, pelo drama da Inconfidência. Não há dúvida de que este tipo de texto muito colaborou para a difusão de uma interpretação tradicional da história do movimento e, sobretudo, de uma imagem heróica de Tiradentes, tendência que já podia ser observada desde o início dos anos 30:

Faz hoje cento e quarenta anos que a cidade presenciou emocionada a execução de Tiradentes. Era o epílogo do glorioso sonho dos inconfidentes mineiros de 1789. Supliciado o valoroso soldado, dispersos pelos degredos da África os demais conjurados, julgava o governo de Lisboa estar aniquilando no Brasil o anseio de liberdade. Puro engano ${ }^{22}$.

Comemora-se a 21 de abril a passagem do aniversário da morte de Joaquim José da Silva Xavier — o Tiradentes — bravo mineiro que, em 1792 resgatou com a vida o crime de conspirar contra o domínio português no Brasil, tornando-se o grande precursor de nossa independência política ${ }^{23}$.

Os dois textos, além de ressaltar a dimensão sacrificial, não deixam de externar o peso do domínio português sobre o Brasil. O segundo autor, depois de deter-se longamente na biografia de Tiradentes, na qual enfatiza sua predisposição para a luta, sua indignação com as injustiças e sua coragem ao se rebelar, conclui com o enforcamento de Tiradentes, ofim trágico de uma vida que, ansiosa de liberdade, vibrante de patriotismo, um dia cometeu o crime de se insurgir contra o domínio estrangeiro em sua terra ${ }^{24}$. Embora não exclusivas da década de 30, as idéias de patriotismo e de nacionalismo tinham nesta 
época significado mais acentuado e, associadas a um episódio tão valorizado na história brasileira, ganhavam, certamente, em legitimidade. A referência ao domínio estrangeiro em sua terra poderia expressar o entendimento da existência, já no século XVIII, de um sentimento nacional formado, legitimando, pelo passado, as lutas nacionalistas daquele presente. Poderia ainda fazer referências indiretas aos recentes acontecimentos, ligados aos embates com os comunistas, vistos pelo regime como ameaças à integridade e soberania nacionais, resultantes de uma nefasta influência externa ${ }^{25}$.

O segundo tipo de texto, aqui chamado de romanesco, construía, sobre as versões historiográficas existentes, situações idealizadas envolvendo Tiradentes, nas quais suas qualidades excepcionais eram agigantadas, reforçando sua condição heróica. Muitas vezes eram textos da fatura de membros de institutos históricos, além de saírem também da pena de literatos:

Tiradentes, a cavalo, com a mão esquerda segurava as rédeas e com a direita abria a porteira do curral da fazenda de Varginha. Apeava-se e era recebido na varanda onde grossas colunas, capazes de sustentar, não o telhado, mas torres de pedra, davam à casa o aspecto de fortaleza tranqüila de sua segurança e inexpugnabilidade ${ }^{26}$.

Nesse texto, o então diretor do Instituto Histórico e Geográfico de Ouro Preto buscava inspiração na narrativa ficcional para falar dos encontros de Tiradentes com seus companheiros, e imaginar situações vividas pelo alferes, que teriam tido influência no desenvolvimento de suas idéias revolucionárias. Aqui, numa fazenda, ele veria o sofrimento dos escravos e refletiria sobre a necessidade da abolição da escravidão no Brasil.

$\mathrm{Na}$ composição de textos de natureza romântica, a vida pessoal de Tiradentes ganharia maiores atrativos quando alguns autores procuraram explicar sua trajetória até a conspiração em função de suas desventuras amorosas. Um artigo publicado no Diário de Minas, depois de comparar fisicamente Tiradentes aos astros do cinema brasileiro da época, brindava os leitores com uma narrativa que bem poderia se tornar um roteiro para as telas. Vale a pena resgatá-lo, apesar de sua extensão:

Aos vinte anos de idade teve a sua grande paixão amorosa. $\mathrm{O}$ amor que mudou os rumos de sua vida. $\mathrm{O}$ amor que permaneceu na memória do tempo e abriu outros roteiros na jornada do herói.

Ele amou como criatura humana. Teve seus sonhos líricos, balbuciou juras de eterno amor, sentiu nos lábios o doce gosto dos beijos que nascem na fonte pura do coração. Tiradentes teve o seu primeiro e grande amor na figura de Maria, uma jovem filha do ourives de São João del Rey. (...) Maria encheu-lhe a vida de 
ternura e lirismo. Era bela nos seus quinze anos. Dotada sob todos os pontos de vista. O pai, reinol orgulhoso, se opôs ao romance pois não consentiria que sua filha primogênita se casasse com colono, caboclo moreno. E o namoro foi desfeito sob o impacto reacionário do pai cheio de preconceitos. Ficaram apenas as recordações dos encontros secretos nos labirintos da casa da Pedra na cidade de Tomé Pontes e Tancredo Neves. Para esquecê-la sentou praça. Andou pelos matos, pelos sertões, pelas minas, pelas encruzilhadas. Maria, porém, ocupava definitivamente um lugar no largo coração do moço Joaquim José da Silva Xavier, cujos irmãos mais velhos foram sentar praça no invencível Exército de Cristo, tomando hábito.

Outras mulheres passaram pela vida do futuro alferes e mártir da liberdade. Nenhuma conseguiu eclipsar aquela doce Maria, de fala doce, olhar suave como estampa de santa, de cabeleira solta aos beijos da brisa vespertina.

Apenas uma adorável criatura encheu o claro aberto pela fuga de Maria. Deulhe carinho e dois filhos. Deu-lhe a constância de um amor que se projetou na história. Era a companheira do herói, a musa do conspirador, a confidente do sonhador consciente, Eugenia Maria de Jesus é a grande companheira de Tiradentes. Amor nascido nas sombrias e misteriosas noites de Vila Rica. Dizem que era linda, alta, olhos grandes e pretos como aqueles contados no "Gondoleiro do Amor", de Castro Alves. Poderia muito bem ser chamada Eugenia Maria de Jesus, a Marília do Alferes. Foi-lhe fiel. Esperava-o sempre de suas peregrinações audaciosas pelos sítios e veredas. Guardava para o amante o relicário de suas ternuras. Alisava os revoltos cabelos do herói inquieto. Consertava suas camisas, suas vistosas fardas, limpava suas botas, e à noite, solfejava canções de amor, com o travo da melancolia, para o acalanto do bem amado. Eugenia Maria de Jesus, a companheira fiel de Tiradentes, com a morte do herói e o seqüestro de todos os seus bens (...) fugiu de Vila Rica. Sob a proteção do comerciante Belchior Beltrão, amigo do alferes, Eugenia tomou o rumo do Quartel Geral, próximo de Dores do Indaiá, onde viveu alguns anos com os dois filhos cujo pai foi o mártir inigualável da liberdade política do Brasil ${ }^{27}$.

$\mathrm{O}$ autor procurava preencher uma lacuna na biografia de Tiradentes, cara às histórias dos heróis: a mulher amada, a companheira. Poucas foram as obras que se detiveram sobre este aspecto da vida de Joaquim José da Silva Xavier. Uma das exceções é o livro Tiradentes, de Oiliam José, que dedicou ao tema o capítulo "Fraquezas de Homem". O autor, depois de uma rápida análise do ambiente moral colonial no qual se inseria Tiradentes, dizendo que ele vivia as liberdades que a sociedade mineira do tempo aceitava ou, pelo menos, tolerava, desculpa o comportamento do herói, pois 
(...) o amor está presente em toda vida humana, para conduzi-la a um dos dois extremos que se opõem irremediavelmente: os píncaros da santidade e as abjeções do satanismo. E, entre um extremo e outro, colocam-se as gradações mais diversas. Numa dessas, ficaria bem classificar o amor terreno, passageiro de Tiradentes, que, sem atentar em sua condição de cristão, sorveu as volúpias dos sentidos. Felizmente, porém, o Alferes não permaneceu pelo resto da vida nesses declives morais. Redimiu-se corajosamente. Abraçou a virtude. Tornou-se modelo de arrependimento e moralidade. Fez-se herói também no penoso terreno das paixões humanas. Morreu vivendo as severas exigências da moral cristã $!^{28}$

Mais preocupados com a conspiração e com as idéias revolucionárias do inconfidente, os textos geralmente passavam ao largo de qualquer comentário a respeito do tema, ou simplesmente mencionavam a existência de Eugenia Maria de Jesus, como mãe da única filha de Tiradentes. Evitando o assunto, essas obras tanto poderiam expressar uma real falta de interesse por ele quanto o temor, principalmente dos intelectuais católicos, de reconhecer em Tiradentes práticas e códigos morais diferentes dos aceitos e defendidos por eles. Afinal, o alferes nunca se casou, viveu em concubinato, freqüentava as "casas de alcouce" e poderia ter tido filhos naturais.A abordagem romântica também ancorava-se fortemente no caráter humanitário de Tiradentes, descrito como um indivíduo acima dos demais por ter superado moralmente eventuais desvantagens de natureza material ou social. Este seria o principal traço definidor e mais valorizado de um herói, ou seja, el móvil ético de su acción, fundado éste en un principio de solidaridad y justicia social ${ }^{29}$, e por isso tomado como modelo por suas ações. Elemento importante na construção da representação do herói, este caráter humanitário serviu à produção de textos de divulgação, publicados nos jornais, que considero importantes na consolidação de uma visão pouco crítica da história. Nesses textos a estratégia estilística mais utilizada, como já foi apontado, era a de romancear informações vindas das obras historiográficas, que nessa época já eram, por si sós, bastante adocicadas. Temos um exemplo em artigo publicado em 1957:

Ele costumava ver, nas suas idas de Minas ao Rio, as matas verdes à beira das estradas. Ouvia encantado o gorjeio dos pássaros que pululavam de galho em galho, numa movimentação constante, livres, inteiramente livres... E matutava:

— Por que só a minha terra — essa vastidão de abundância — precisa continuar cativa, sem esperanças de uma liberdade a que já tem direito?

(...) Joaquim José da Silva Xavier habituara-se a ver a Pátria berço de seus antepassados, subjugada. Mas não se conformava. Ele nascera quando já o povo gemia sob a opressão de impostos altos e acumulados. Perdera cedo os pais. Seus dois irmãos abraçaram a carreira do sacerdócio. Viviam longe, internos, e as ir- 
mãs estavam distantes, distribuídas pelas casas de parentes. Nem um vislumbre de afeição sincera. Era de extrema solidão sua existência. Porém compensou-se pelo amor sem limites à Pátria. Analisou-lhe os problemas, apaixonou-se pelo maior deles: a independência.

Passou a viver com o povo. Para ele tinha sempre palavras justas e oportunas. Fez amigos entre a gente de Minas, ora no Rio. Criou fama a sua habilidade em tirar e pôr dentes. (...) Entre a classe mais favorecida pela sorte ou entre a população quase mendiga, ia crescendo uma veneração por aquele homem generoso que exercia a sua missão quase de graça, por vezes facilitando os pagamentos, por vezes esquecendo as dívidas de seus clientes. Observador, de olhar triste, calado, ia ouvindo os queixumes daqueles que o procuravam.

"Como é infeliz o povo brasileiro", pensava a cada queixume feito. E pensava: "Isto precisa acabar". Silva Xavier cismava com épocas de glória. Cada vez mais querendo estar em relação com todas as classes sociais, foi alternando o seu meio de vida. Se já havia conhecido de perto a gente brasileira, agora podia verificar a riqueza do solo.

- Que injustiça! Passam fome tantos irmãos, quando a terra tem tesouros para saciar-lhes toda a pobreza, gritava-lhe a consciência cada vez mais alto ${ }^{30}$.

A extensão dessa transcrição justifica-se por já termos aqui, além de um texto de natureza romântica, o esboço do terceiro tipo ao qual me referi, o texto cristão. Impressiona a cristianização dessa "biografia" de Tiradentes: o homem solitário, sofrido e solidário, que teve como principal meta na vida a conquista da liberdade, não para seus compatriotas, mas para seus irmãos. $\mathrm{O}$ uso das referências cristãs, tanto nas idéias quanto na linguagem é clara. Considerando as analogias, já conhecidas, entre o drama de Tiradentes e de Jesus, não poderia faltar, num texto dessa natureza, a referência ao traidor, o Judas da Inconfidência, responsável, em última análise, pela derrota do movimento e pela condenação do herói-mártir. Continuemos a explorar esse curioso documento:

Ouro Preto - a rica terra mineira - era lugar de homens ilustres e também idealistas. Começaram eles a traçar planos, fazendo programas, distribuindo missões entre si. Era a conspiração contra os opressores estrangeiros que se formava. E Tiradentes serviria de elo entre as províncias vizinhas. Ninguém percebia porém a chama da liberdade que se inflamaria em breve.

Mas... quem nunca ouviu dizer "uma ovelha má põe um rebanho a perder"? Houve uma ovelha má entre os conspiradores. Percebendo que ficaria bem com os que então mandavam na terra, só pensou em si. Traiu os companheiros. Revelou todos os planos. Aquele homem não era brasileiro. Talvez por isso não ti- 
vesse entendido a grandeza do movimento e não sentisse anseios de independência.

Houve prisões, julgamentos. Tiradentes pagou com a vida, em praça pública, o sonho bom que tivera para a Pátria. Morreu como um justo. Rezava nos últimos momentos. Implorava por certo a Deus que a chama da liberdade, que naquela hora amortecia, nunca extinguisse nos corações de seu povo. Aquele que morreu pela liberdade, viu seus rogos atendidos. Não demorou muito e o próprio Regente das terras opressoras concretizava o sonho de Tiradentes com um grito que reboou pela terra afora: Independência ou Morte ${ }^{31}$.

Além de estar permeado de elementos constituintes da representação sacralizada, este texto indica alguns dos meios pelos quais ela vem se firmando no imaginário, como tem sido apropriada pelas mais variadas formas de discurso, e através de que mecanismos ela tem se perpetuado. Deve-se considerar o significado de textos como o transcrito acima, na medida em que as obras da historiografia tinham - como infelizmente ainda têm — circulação restrita, mesmo entre a população letrada, ou escolarizada. Os jornais, ainda que de acesso limitado no período do qual estou tratando, poderiam atingir um público maior e ter ampliado seu papel de difusor daquelas representações. Ainda mais quando expressas por meio de textos simples e acessíveis, permeados de referências religiosas facilmente reconhecíveis e construídos com recursos estilísticos próximos do folhetim. Este tipo de texto aparecia também, com bastante freqüência, nas seções dos jornais destinadas às crianças, ainda mais simplificados e romanceados. Vale lembrar, ainda, que a sua difusão era ampliada por meio das transmissões radiofônicas, nas quais eles eram lidos ou dramatizados, geralmente como parte das programações comemorativas de 21 de abril.

Este texto, como tantos outros semelhantes publicados nos jornais, não contém o registro de sua autoria. Saídos da imaginação dos jornalistas, editores e colaboradores, eles dividiam espaço com os noticiários sobre a comemoração do 21 de abril e também com as transcrições dos discursos das autoridades convidadas para a celebração. A década de 50 foi particularmente pródiga, não tanto nos discursos - que estes, desde o aparecimento desta festa cívica sempre ocorreram — mas na sua reprodução nas páginas dos jornais de maior circulação ${ }^{32}$.

A natureza cristianizada dessas falas não tinha exclusividade, estando presente nos discursos de políticos, intelectuais, militares e, claro, clérigos, saltando para as páginas dos jornais em formas diversas, expressando uma apropriação dessa representação de Tiradentes mais generalizada do que poderíamos supor. E, quando associada à exaltação patriótica, de fatura regionalista, produziam-se algumas jóias como esta: 
Nosso pai Tiradentes é História viva no chão de vulcões mortos de Minas; neste chão ora espraiado em várzeas, onde o milho, a laranja, as "quaresmas" e as "angélicas" sinfonizam coralmente e inouvidamente.

Com caraças alpinas de ferro e manganês, com rios volgueanos, com lagoas azuis ou cor de chumbo;

no chão desta Província, ora empenado com um eco ameríndio de outras altitudes geofísicas e geopolíticas da Europa matriz dos sonhos que te elegeram, Minas Gerais, a terra amena dos vinhedos de Caldas, dos trigais de Patos; dos pinheiros e dos nevoeiros da Mantiqueira; e das relvas macias e dos rebanhos multicoloridos do Katiavar [do teu sul temperado;

e das emas e avestruzes do teu Triângulo ondulado, e dos lobos vermelhos que uivam nas tuas brenhas altas. Fausto destino da cultura da Euro-América, Arcádia morta... Minas Gerais ${ }^{33}$.

Um certo ufanismo regional — se é que se pode falar nesses termos — votado à exaltação de Minas Gerais pode ser vislumbrado neste poema. Um ufanismo que vê Minas como uma terra predestinada, uma espécie de síntese de várias terras, propícia para a frutificação dos ideais libertadores de Tiradentes. Temos aqui, junto à exaltação patriótica, o apelo cristão. Mesmo mais recentemente, quando se poderia, à primeira vista, imaginar a perda de sentido, ou da força daquela visão, ainda aparecem na imprensa - menos profusamente, é verdade - textos dedicados à aproximação entre Tiradentes e Cristo, como esta pequena nota, publicada no jornal Estado de Minas, em abril de 2000:

Hoje o coração do povo brasileiro vivencia a emoção de dupla cerimônia: uma religiosa e outra cívica, quando celebra-se a Sexta-feira da Paixão e o Dia de Tiradentes, embora as comemorações alusivas a este último tenham sido transferidas para o dia $1^{\circ}$ de maio, justamente por causa da Sexta-Feira Santa. Coincidentemente, Cristo e Tiradentes morreram por causas nobres, visando o bem estar do homem. Cristo por pregar a verdade, o amor, a paz, a igualdade, na tentativa de libertar o homem do pecado. Tiradentes, por pregar e lutar pela tão sonhada liberdade do povo brasileiro, explorado e massacrado pela Coroa portuguesa, e por querer fazer deste País uma verdadeira nação. Um na cruz, outro na forca. Cristo após crucificado e sepultado, ressuscitou três dias depois, e hoje, em qualquer parte do planeta onde houver um cristão, o seu nome será aclama- 
do e venerado. Tiradentes, depois de enforcado no Largo da Lampadosa, no ensolarado sábado de 21 de abril de 1792, teve o seu corpo esquartejado e espalhado pelas estradas de Minas, para servir de exemplo. É intrigante. Uma pergunta cuja resposta nunca convence. Por que as pessoas de bem, honestas e dedicadas às causas alheias pagam tão alto por seus nobres gestos? $?^{34}$

Guardadas algumas diferenças estilísticas, este texto poderia ter sido publicado em qualquer momento do período em foco. Sua estrutura é a mesma daqueles datados da segunda metade do século XIX, nos quais a analogia entre Tiradentes e Cristo, entre os mártires cristão e cívico, era mais comum. Ele contém, ainda, um encerramento de fundo moral, com ênfase na idéia do sacrifício, demonstrando claramente sua concepção de história maniqueísta. São textos como esses, publicados há décadas nos jornais, de pequena ou grande circulação, que têm contribuído eficazmente para a manutenção das representações de Tiradentes em foco neste artigo.

Além de publicarem textos como os que vimos acima, os jornais reservavam espaço também para os editoriais a respeito das comemorações do 21 de abril e para a transcrição dos discursos pronunciados pelas autoridades nesta ocasião, junto ao noticiário sobre essas festas. Esses textos estavam mais claramente relacionados à conjuntura política da época e podiam expressar os posicionamentos e os confrontos de cada momento:

Os tempos, porém, passaram e o Brasil, sob a alvorada da Democracia e da República, tem sabido consagrar à memória do Mártir e dos seus companheiros, mais crescendo ano a ano, o entusiasmo cívico das comemorações.

O Brasil Novo, rejuvenescido pela integração em si mesmo, uno, forte, redivivo em todas as suas energias vitais, sob a chefia unida de seu grande vanguardeiro, Presidente Vargas, mais do que nunca tem dado à Glória dos inconfidentes a sagração histórica merecida ${ }^{35}$.

Embora, como os demais textos, os discursos proferidos pelas autoridades não excluam as referências sacralizantes, eles tinham objetivos outros, além da pura e simples exaltação. Há, aqui, uma clara finalidade de interligação entre a comemoração cívica e a atuação política, o que os torna termômetros do cenário político brasileiro e mineiro no período examinado. A inserção desses discursos no campo do confronto político permite identificar algumas de suas características, no que diz respeito, sobretudo, às articulações construídas entre o passado e o presente, como forma de legitimação.

Exemplo elucidativo a respeito foi o pronunciamento feito em 1939 pelo general Meira de Vasconcelos, comandante da $1^{a}$ Região Militar, lembrando o heroísmo de Tiradentes como modelo para as lutas contra o que se conside- 
rava, então, como os principais perigos que pairavam sobre a nação, isto é, o comunismo e a ameaça de guerra:

A comemoração do feito de Tiradentes é, pois, uma exaltação de que nos devemos orgulhar, honrá-la e glorificá-la, pela significação moral que marcha, se avoluma e se eleva com os tempos. Ela é o protesto contra o domínio, contra a extorsão, assédio econômico, e nos tempos que vivemos, vendo flutuar o pavilhão das cores deslumbrantes da jornada de 1822, assistimos à renovação multiforme desse cerco, a ameaça de povos contra nós, a política de infiltração perigosa que encontra a seu favor uma coletividade de educação falha de civismo, displicente, vivendo apenas a existência regional e perigosa pela incompreensão dos deveres que enfeixam problemas nacionais. (...) A época traz para nós acréscimos de deveres, eles se multiplicam, exigem que ingressemos toda a nação na política de segurança, educando-a em rumos que permitam à coletividade brasileira se alistar para a batalha dos tempos atuais, onde nenhum deve faltar, para que o patrimônio secular não faça parte da repartição que a truculência internacional premedita, já com pontos de apoio no Continente e pense assim dispor de nossa soberania.(...) Cumpramos o nosso dever prosseguindo a velha e tradicional política do Brasil, dentro do espírito de harmonia, mas conscientes de que podemos impor, mesmo pela força, nossa vontade contra quem quer que ameace a nossa integridade ${ }^{36}$.

Divulgados pela imprensa, esses discursos contribuíam para a consolidação das representações heróicas e sacralizadas de Tiradentes, servindo ainda à legitimação daqueles que delas se apropriavam. Os atos heróicos e sacrificiais do passado encontravam sua continuidade no presente, por meio da ação dos líderes da nação, como ficou claro no pronunciamento de Getúlio Vargas na celebração de 21 de abril de 1954, em Ouro Preto, quando o então presidente da República foi o convidado de honra da cerimônia. Chamando para si a atenção como instrumento dessa luta no tempo presente, Getúlio Vargas apresentou-se quase como um mártir que, como Tiradentes, se sacrificava pelo bem da nação. O presidente não foi sutil nessa comparação e, como uma ironia do destino, parecia antecipar sua entrada próxima no panteão dos mitos políticos brasileiros, no episódio trágico de sua morte, meses depois de ter estado em Ouro Preto:

(...) a distância do tempo não afasta a sua atualidade. É ainda a mesma bandeira que estamos empunhando na luta dos nossos dias, é a luta de um governo legitimamente constituído, de base nacionalista e popular, contra a mentalidade negativista, que descrê do nosso futuro, das nossas possibilidades e reservas da capacidade criadora de nossa gente, enfim que não acredita no Brasil. (...) Bem sei 
como a injustiça, a incompreensão e os processos difamatórios se agregam aos problemas, às dificuldades, às responsabilidades das grandes obras planejadas e empreendidas. (...) Deus é testemunha do quanto tenho feito, vencendo até os impulsos mais íntimos para amainar as paixões, apaziguar os espíritos, desarmar as prevenções, reunir a todos num só esforço pelo progresso do País. Nada me desviará dos rumos que eu tracei, porque as vozes agourentas não conseguem fazer do branco preto, nem convencem de isenção quando só procuram dissensão. Entendo que o governo é escola de humildade, aprendizado de disciplina, que exige a renúncia a si próprio e o domínio dos ressentimentos, para só cuidar dos interesses reais da Nação ${ }^{37}$.

Os afagos de Vargas dirigiam-se, então, para Minas Gerais, cujo governo, sob a batuta de Juscelino Kubitschek, demonstrava, naquele momento, apoio às suas posições. No discurso, o presidente apontava Minas como o lugar ideal para a busca do consenso e da harmonia, exaltando as tradições mineiras que poderiam serenar os espíritos exaltados daquele momento político delicado. Voltava-se, também ele, ao passado, e buscava em Tiradentes, mais uma vez, sustentação e legitimação. Os apelos nacionalistas vinham no momento dos mais duros embates entre Vargas e a oposição, quando ele acirrava seus ataques aos investidores estrangeiros e tentava a ampliação da base econômica estatal. Não permitir que os interesses mesquinhos se sobrepusessem aos interesses da nação seria a tarefa do governo, que deveria

(...) garantir a ordem, a liberdade, a coesão, a prosperidade econômica e a justiça social. (...) Para o seu pleno cumprimento não mediremos os sacrifícios. E aqui, neste dia glorioso, devemos renovar e revigorar esse irredutível propósito. O exemplo de Tiradentes e a lição de Minas nos darão força para construir no futuro um Brasil que corresponda aos sonhos do passado e em que se alcancem as esperanças do presente ${ }^{38}$.

Aproveitando o mote dado pelo poema analisado anteriormente e suas referências regionalistas, vejamos um pronunciamento do governador de $\mathrm{Mi}$ nas Gerais, na festa de 21 de abril de 1955, em Ouro Preto, no qual evidenciase o discurso de exaltação a Minas e a seu papel na política nacional como uma herança advinda dos tempos da Inconfidência Mineira. Naquele momento, Juscelino Kubitschek, já em campanha para a presidência da República, foi o grande homenageado, eclipsando, por um instante, o próprio Tiradentes:

Esta cerimônia tem suas raízes aprofundadas no solo ardente das mais severas virtudes públicas da gente mineira e está carregada de um sentido cívico que vive e fulgura nas três dimensões do tempo — passado, presente e futuro — por- 
que é eterno. Em verdade nesta cerimônia se cultuam duas faces fundamentais do caráter dos mineiros, que constituíram, constituem e constituirão, tempo em fora, os seus cunhos distintivos, a saber: o amor à terra natal e a vocação da liberdade. Essas duas expressões da nacionalidade, que se exigem uma a outra para integrarem-se e completarem-se em unidade autêntica, essas duas projeções da alma coletiva sem as quais não há povo e que só elas criam, nutrem e explicam as nações, porque somente elas são capazes de inspirar a vigilância, o sofrimento e o sacrifício por um bem impessoal - esses dois pólos de atração e condensação da vontade de ser e de durar que caracterizara historicamente os grupos sociais coerentes, lúcidos e poderosos, encontraram na imensa figura moral do Alferes Joaquim José da Silva Xavier o seu perfeito instrumento de expressão numa hora densa e aguda do nosso país em fase de penosa formação. (...) Convidando a falar, nas comemorações de hoje, o sr. Juscelino Kubitschek, quis o governo mineiro exprimir de modo público e eloqüente, não só o apreço em que o tem, senão também o apreço com que acolheu a sua bela iniciativa.(...) $\mathrm{O}$ meu governo não se limitou a recolher a valiosa herança deixada pelo governo de V. Excia. Exmo. Sr. Dr. Juscelino Kubitschek: deliberou ampliar as comemorações inauguradas em 1952, enriquecendo-as, variando-as, estendendo-as no tempo ${ }^{39}$.

O governador Clóvis Salgado, no cargo devido ao afastamento de Juscelino Kubitschek para a campanha eleitoral, usou deliberadamente a festa de 21 de abril para homenagear o futuro presidente da República. JK, por sua vez, não perderia a oportunidade, em seu discurso, de estabelecer paralelos entre a trajetória de Tiradentes e a sua própria.

Nesta última forma de discurso, os exercícios de interligação entre o passado e o presente foram, assim, os mais recorrentes, escritos e pronunciados por pessoas com posições políticas diversas, de diferentes segmentos sociais, com objetivos também diversos. Mesmo quando em muitos desses discursos Tiradentes acabou por ficar em segundo plano, sua condição de precursor da Independência e herói nacional jamais foi questionada. Claro, não se poderia esperar outra posição das falas oficiais, no momento da celebração cívica. Mas analisando todos os tipos de textos publicados nos jornais - o que inclui as transcrições de discursos oficiais, mas também outras modalidades, conforme visto anteriormente - é inexpressiva a contestação a Tiradentes. O jornal Binômio, conhecido por suas ácidas investidas contra o governo, fartavase nas críticas às comemorações oficiais, mas sugestivamente mantinha Tiradentes em seu pedestal:

Todos os poderes da nação arranjaram as malas para a mudança e sua inauguração é trombeteada aos quatro cantos do mundo, através de desenfreada maté- 
ria que o sr. Juscelino Kubitschek distribuiu à imprensa nacional e estrangeira. Não serão, no entanto, fotografias coloridas e a bela arte de Niemeyer e Lúcio Costa que vão provar estar Brasília em condições de ser inaugurada. Trata-se de uma farsa, muito ao gosto de J.K. Um mérito, no entanto, não podemos negar ao Presidente da República: com a "inauguração" de Brasília ele consegue, em 1960, fazer coincidir o $1^{\circ}$ de abril com a grande data de Tiradentes ${ }^{40}$.

Assim, as representações de Tiradentes são aceitas quase como uma unanimidade, em épocas diferentes, expressando diferentes posições. Na verdade, a contestação e o questionamento aparecem contra as tentativas de revisão e de relativização, tanto do movimento setecentista, quanto, e principalmente, de seu principal personagem.

Promovendo a circulação das representações predominantes de Tiradentes, os jornais tornaram-se veículos de sua consolidação ao longo do século XX. Mesmo considerando-se as limitações do público leitor, inclusive atualmente, não se pode minimizar o poder desse veículo de comunicação na afirmação daquelas representações. No período em que a atenção à memória de Tiradentes foi mais intensa por parte do mundo oficial - como ocorreu entre as décadas de 30 e 60 - a imprensa marcou sua participação ampliando os espaços para a publicação de textos os mais diversos e para a cobertura das comemorações, realizadas nos mais diferentes lugares.

Especialmente em Minas Gerais, os jornais acabaram por tornar-se porta-vozes de uma versão oficial da história, e de uma posição francamente favorável à exaltação patriótica de Tiradentes. Entre os que foram pesquisados, o único ainda remanescente, o Estado de Minas, mantém essa postura, não obstante publique entrevistas com historiadores da vertente revisionista, em matérias nas quais procura polemizar as divergências historiográficas. Mas a "voz" do jornal se faz ouvir, por meio de editoriais e de algumas colunas assinadas, dos seus quadros fixos. E nelas, não raro, apela-se ainda para os clássicos defensores de uma história da nação:

O Brasil é o único país da América em que existe, há mais de um século, uma campanha sistemática de desmoralização do precursor da independência." Essa frase de Waldemar de Almeida Barbosa resume um dos paradoxos da historiografia brasileira. Paradoxo que não chega a ser espantoso porque volta a comprovar o complexo de inferioridade e síndrome de catástrofe que envolvem a cultura nacional ${ }^{41}$.

Esse é o pretexto para o jornalista, ferrenho defensor de uma representação heróica de Tiradentes, retomar sua série de investidas contra o que ele considera paradoxos da historiografia brasileira, ou seja, o revisionismo. 
Esta análise da produção jornalística sobre o herói nacional procurou identificar os principais elementos constituidores daqueles textos, destacando os que têm evidente enraizamento no universo cultural brasileiro e que, por isso, apresentam uma longevidade considerável. A constatação de elementos que têm se mantido desde o século XIX indica, por um lado, a vitalidade do mito e, por outro, o poder persuasivo das associações estabelecidas, entre o sacrifício heróico de Tiradentes e as condutas dos que se colocam como seus herdeiros.

\section{NOTAS}

${ }^{*} \mathrm{O}$ presente artigo é resultado da pesquisa desenvolvida para a tese de doutorado em História Social, intitulada Da infâmia ao altar da pátria: memória e representações da Inconfidência Mineira e de Tiradentes, defendida em agosto de 2001 no Departamento de História da Universidade de São Paulo e contou com financiamento do CNPq.

${ }^{1}$ Sobre o papel da imprensa na política brasileira, e como fonte de pesquisa para o historiador, ver: CAPELATO, Maria Helena Rolim. Imprensa e História no Brasil. São Paulo: Contexto/EDUSP, 1988. CAPELATO, Maria Helena Rolim. Os arautos do liberalismo: imprensa paulista (1920-1945). São Paulo: Brasiliense, 1989; NEVES, Lúcia Maria Bastos Pereira das \& MOREL, Marco (orgs.). História e imprensa. Anais do Colóquio. Rio de Janeiro: UERJ/IFCH, 1998. Sobre as relações entre a mídia e a política ver: JEANNENEY, Jean-Noël. A mídia. In RÉMOND, René (org.). Por uma história política. Rio de Janeiro: Editora UFRJ, 1996. Um panorama das relações entre a imprensa e a política, no Brasil do século XX, está na bibliografia de MORAIS, Fernando. Chatô: o rei do Brasil. $3^{a}$ ed. São Paulo: Companhia das Letras, 1999. Ver, também: LINHARES, Joaquim Nabuco. Itinerário da imprensa de Belo Horizonte: 1895-1954; estudo crítico e nota biográfica de Maria Ceres Pimenta S. Castro. Belo Horizonte: Fundação João Pinheiro, 1995; SODRÉ, Nelson Werneck. História da imprensa no Brasil. Rio de Janeiro: Civilização Brasileira, 1966; WERNECK, Humberto. O desatino da rapaziada: jornalistas e escritores mineiros. São Paulo: Companhia das Letras, 1992.

${ }^{2}$ Ver: GRAVATÁ, Hélio. “Contribuição bibliográfica para a História de Minas Gerais — Período Colonial — Inconfidência Mineira”. In Revista do Arquivo Público Mineiro. Belo Horizonte: Arquivo Público Mineiro, 1978. Neste levantamento, foram compilados 1.093 títulos de obras da mais variada natureza, relativas à Inconfidência Mineira, excluindo-se os documentos manuscritos e obras gerais de História do Brasil, de Minas Gerais e do Rio de Janeiro. Entre as obras levantadas, produzidas entre 1819 e 1976, encontram-se documentos transcritos e publicados, bibliografias, livros, capítulos e referências em outras obras, verbetes em enciclopédias e dicionários, artigos, discursos, conferências, legislação, literatura, teatro, filmes, iconografia e monumentos. Há também outros levantamentos que incluem, além da bibliografia, fontes documentais disponíveis em arquivos brasileiros. Ver: CARNEIRO, Edilane de Almeida \& SANTOS, Maria Judite dos. "Fontes documentais mineiras: subsídios para o estudo do movimento inconfidente de 1789". In Acervo — Revista 
do Arquivo Nacional. Rio de Janeiro: Arquivo Nacional, v.4, n.1, jan/jun.1989; FIGUEIREDO, Luciano Raposo de Almeida. "Cortando rente o passado... Fontes para a história da Inconfidência Mineira e o acervo do Arquivo Nacional do Brasil”. In Análise \& Conjuntura. Inconfidência Mineira e Revolução Francesa - Bicentenário: 1789-1989. Belo Horizonte: Fundação João Pinheiro, v.4, n.2-3, mai/dez.1989; MATHIAS, Herculano Gomes. "A documentação da Inconfidência Mineira”. In Revista do Instituto Histórico e Geográfico Brasileiro. Rio de Janeiro, ano 153, n.375, abr/jun.1992; PESSOA, Gláucia Tomaz de Aquino. "O acervo do Arquivo Nacional e a história da Inconfidência Mineira”. In Acervo Revista do Arquivo Nacional. Rio de Janeiro: Arquivo Nacional, v.4, n.1, jan/jun.1989.

${ }^{3}$ SILVA, Joaquim Norberto de Souza. História da Conjuração Mineira. Rio de Janeiro: Imprensa Nacional, 1948.

${ }^{4}$ SANTOS, Lúcio José dos. A Inconfidência Mineira: papel de Tiradentes na Inconfidência Mineira. Belo Horizonte: Imprensa Oficial de Minas Gerais, 1972.

${ }^{5}$ BARBOSA, Waldemar de Almeida. A verdade sobre Tiradentes. Belo Horizonte: Instituto de História, Letras e Arte, s/d; JARDIM, Márcio. Sintese factual da Inconfidência Mineira. Belo Horizonte: Instituto Cultural CODESER, 1988; JOSÉ, Oiliam. Tiradentes. Belo Horizonte: Imprensa Oficial, 1974; LIMA JÚNIOR, Augusto de. História da Inconfidência de Minas Gerais. Belo Horizonte: Imprensa Oficial, 1955; PERRIN, Dimas. Inconfidência Mineira: causas e conseqüências. Belo Horizonte: Edições Júpiter, 1985; TORRES, Luis Wanderley. Tiradentes: a áspera estrada para a liberdade. São Paulo: Obelisco, 1965; GRIECO, Donatello. História Sincera da Inconfidência Mineira. Rio de Janeiro: Record, 1990.

${ }^{6}$ João Pinto Furtado chama a atenção para a pouca disposição da historiografia mais acadêmica em tratar da Inconfidência Mineira, história muito marcada pelo tom tradicional, exaltador e oficial. Ver: FURTADO, João Pinto. Historiografia oitocentista americana como "obra de pensamento" que se faz ação (notas para o estudo dos discursos de fundação sob o ponto de vista da epistemologia histórica). In: SCHMIDT, Rita Terezinha (org.). Nações/Narrações: nossas histórias e estórias. Porto Alegre: ABEA, 1997.

${ }^{7}$ MOTA, Carlos Guilherme. Idéia de revolução no Brasil (1789-1801). Petrópolis: Vozes, 1979.

${ }^{8}$ MAXWELL, Kenneth. A devassa da devassa: A Inconfidência Mineira: Brasil e Portugal (1750-1808). Rio de Janeiro: Paz e Terra, 1978.

${ }^{9}$ FURTADO, João Pinto. Inconfidência mineira: crítica histórica e diálogo com a historiografia. São Paulo: FFLCH/Universidade de São Paulo, 2000. (Tese de Doutorado)

${ }^{10}$ SOUZA, Laura de Mello e. Norma e conflito: aspectos da História de Minas no século XVIII. Belo Horizonte: Editora UFMG, 1999; ANASTASIA, Carla Maria Junho. Vassalos rebeldes: violência coletiva nas Minas na primeira metade do século XVIII. Belo Horizonte: C/Arte, 1998.

${ }^{11}$ Ver, especialmente: Análise \& Conjuntura. Inconfidência Mineira e Revolução Francesa Bicentenário: 1789-1989. Belo Horizonte: Fundação João Pinheiro, v.4, n.2-3, mai/dez.1989; ANDRÉS, Aparecida (org.). Utopias: sentidos Minas imagens. Belo Horizonte: Editora UFMG, 1993; Seminário Tiradentes, hoje: imaginário e política na República brasileira. 
Anais... Belo Horizonte: Fundação João Pinheiro, 1994; NOVAES, Adauto (org.). Tempo e História. São Paulo: Companhia das Letras, 1992.

${ }^{12}$ CARVALHO, José Murilo de. A formação das almas: o imaginário da República no Brasil. São Paulo: Companhia das Letras, 1990.

${ }^{13}$ AGULHON, Maurice. Marianne au combat: l'imagerie et le symbolique républicaines de 1789 a 1880. Paris: Flammarion, 1979.

${ }^{14}$ DUTRA, Eliana Regina de Freitas. "Inconfidência Mineira: memória e contra-memória”. In Varia História. Belo Horizonte: Departamento de História-FAFICH/UFMG, n.12, 1993; ALKMIN, Sérgio Vaz. "Inconfidência Mineira: a vida histórica do acontecimento". In Revista do Tribunal de Contas do Estado de Minas Gerais. Belo Horizonte: TCMG, v.21, n.4, out/dez.1996.

${ }^{15}$ Memórias do êxito que teve a conjuração de Minas e dos fatos relativos a ela acontecidos nesta cidade do Rio de Janeiro desde 17 até 26 de abril de 1792, atribuída ao frei José Carlos de Jesus Maria do Desterro, e Últimos momentos dos Inconfidentes de 1789, pelo frade que os assistiu em confissão, de frei Raimundo da Anunciação Penaforte. Ambos estão publicados em Autos da Devassa da Inconfidência Mineira. 2a ed. Brasília: Câmara dos Deputados; Belo Horizonte: Imprensa Oficial de Minas Gerais, 1980, v.9 e em Revista do Instituto Histórico e Geográfico Brasileiro. Tomo 44, $2^{\circ}$ trimestre, 1881.

${ }^{16}$ Os jornais utilizados na pesquisa foram o Jornal do Brasil, do Rio de Janeiro, o Estado de Minas, o Diário de Minas e o Binômio, todos de Belo Horizonte. A não ser pelo Binômio, fundado em 1952 por estudantes mineiros e progressivamente identificado com as posições políticas de esquerda, os outros representavam posicionamentos conservadores, próximos das elites e, não raro, defensores de seus projetos. O Estado de Minas integrava os Diários Associados, de Assis Chateaubriand, desde 1929; o Diário de Minas havia sido criado em 1898 ligado ao Partido Republicano Mineiro, e desde 1949 pertencia à família Negrão de Lima, ligada ao Partido Trabalhista Nacional, uma das bases de apoio de Juscelino Kubitschek. O Jornal do Brasil surgiu em 1891, foi ativo nos conflitos entre civis e militares no início da República e sempre defendeu posições conservadoras.

${ }^{17}$ Três obras eram as referências básicas para os textos jornalísticos: SILVA, Joaquim Norberto de Sousa. História da Conjuração Mineira. Rio de Janeiro: Imprensa Nacional, 1948. 2v (a primeira edição é de 1873). SANTOS, Lúcio José dos. A Inconfidência Mineira: papel de Tiradentes na Inconfidência Mineira. Belo Horizonte: Imprensa Oficial, 1972 (a primeira edição é de 1927). LIMA JÚNIOR, Augusto de. Pequena história da Inconfidência de Minas Gerais. Belo Horizonte: Imprensa Oficial, 1955.

${ }^{18}$ FRIEIRO, Eduardo. A sombra de Tiradentes. Estado de Minas. Belo Horizonte, 20 de abril de 1952 , p. 5. Este texto foi publicado também no livro O diabo na livraria do cônego, de mesmo autor.

${ }^{19}$ Idem. Grifos meus.

${ }^{20}$ Idem.

${ }^{21}$ FLORENCIO, Fidelis. “Tiradentes vivo”. Diário de Minas. Belo Horizonte, 7 de maio de 1952, p. 4.

22"Tiradentes". Jornal do Brasil. Rio de Janeiro, 21 de abril de 1932, p. 11. 
${ }^{23}$ MAURICIO, Augusto. A Inconfidência Mineira. Jornal do Brasil. Rio de Janeiro, 18 de abril de 1937, p. 15.

${ }^{24}$ Idem.

${ }^{25}$ Ver: DUTRA, Eliana Regina de Freitas. O ardil totalitário: imaginário político no Brasil dos anos 30. Rio de Janeiro: Ed. UFRJ; Belo Horizonte: Ed. UFMG, 1997.

${ }^{26}$ RACIOPPI, Vicente. Tiradentes. Estado de Minas. Belo Horizonte, 22 de abril de 1941, p. 5.

${ }^{27}$ Os amores do alferes. Diário de Minas. Belo Horizonte, 21 de abril de 1954, p. 8.

${ }^{28}$ JOSÉ, Oiliam. Tiradentes. Belo Horizonte: Imprensa Oficial, 1974, p. 63.

${ }^{29}$ BAUZÁ, H. Op. cit.., p. 5. Ver também AUGÉ, Marc. Heróis. In Enciclopédia Einaudi. Religião-Rito. v.30. Lisboa: Imprensa Nacional/Casa da Moeda, 1994.

${ }^{30}$ Tiradentes — o amigo da liberdade. Diário de Minas. Belo Horizonte, 21 de abril de 1957, p. 4. Suplemento Literário.

${ }^{31}$ Idem.

${ }^{32}$ Os discursos eram normalmente publicados no órgão oficial do Estado, o Minas Gerais. A maior incidência da publicação de discursos nos jornais privados é um dado importante para se pensar numa maior difusão das idéias neles existentes. É preciso considerar, no entanto, os possíveis vínculos entre estes jornais e o governo, o que poderia fazer deles divulgadores das idéias e dos projetos oficiais. Uma grande incidência de transcrição de discursos pelos jornais durante a década de 50 explica-se pela preocupação, principalmente 462 do governo de Minas Gerais, então sob batuta de Juscelino Kubistchek ou sob sua influência direta, com a comemoração do 21 de abril, festa tornada oficial e permanente a partir desse momento.

${ }^{33}$ FLORÊNCIO, Fidelis. Poema derrotista a Tiradentes. Diário de Minas. Belo Horizonte, 20 de abril de 1958, p. 1. Suplemento Literário.

${ }^{34} \mathrm{~A}$ morte de Cristo e de Tiradentes. Estado de Minas. Belo Horizonte, 21 de abril de 2000.

${ }^{35}$ As sentenças execrandas contra os Inconfidentes. Estado de Minas. Belo Horizonte, 28 de abril de 1942, p. 6.

${ }^{36}$ Tiradentes. Jornal do Brasil. Rio de Janeiro, 21 de abril de 1939, p. 7.

${ }^{37}$ Não preservam o regime os que engendram ardis para fraudar a vontade do povo. Discurso do presidente Getúlio Vargas. Estado de Minas. Belo Horizonte, 23 de abril de 1954, p. 7.

${ }^{38}$ Idem.

${ }^{39} \mathrm{E}$ uma forma de homenagear também a cidade ilustre. Discurso do governador Clóvis Salgado. Estado de Minas. Belo Horizonte, 23 de abril de 1955, p. 3.

${ }^{40} 1^{\circ}$ de Abril. Binômio. Belo Horizonte, 18 de abril de 1960, p. 1.

${ }^{41}$ SIQUEIRA, Cyro. Tiradentes, a imagem de um País. Estado de Minas. Belo Horizonte, 28 de abril de 2001, p. 10. Caderno EM Cultura.

Artigo recebido em 09/2001. Aprovado em 03/2002. 